\title{
28 Research Suare \\ The Effect of Global Warming and Acidification on PAHs Bioaccumulation in Pearl Oyster Pinctada Radiate
}

Fatemeh Jafari

University of Guilan

Akram Sadat Naeemi ( $\nabla$ a_naeemi@guilan.ac.ir)

University of Guilan https://orcid.org/0000-0001-5340-3047

Mohsen Noorinezhad

Iranian Fisheries Research Organization

Mohammad Mahdi Sohani

University of Guilan

\section{Research Article}

Keywords: Bioaccumulation, Global warming, Ocean acidification, Persian Gulf, Pinctada radiata, Polycyclic Aromatic Hydrocarbons

Posted Date: July 7th, 2021

DOI: https://doi.org/10.21203/rs.3.rs-430826/v1

License: (9) (1) This work is licensed under a Creative Commons Attribution 4.0 International License. Read Full License 


\section{Abstract}

Warming and acidification are expected impact of climate change that will affect marine areas in the future. These areas are, furthermore, vulnerable to strong anthropogenic stresses such as chemical pollutants. Nevertheless, the consequences of both stressors for marine ecosystems and organisms are still unidentified. The present study aims to examine, for the first time, the effect of temperature and $\mathrm{CO} 2$ pressure increase on bioaccumulation of phenanthrene as a PAHs model in four tissues, gills, digestive gland, muscle and mantle of a commercially important pearl oyster Pinctada radiata. Oysters were exposed to various combination of the ambient temperature and $\mathrm{pH}$ currently measured in Persian Gulf ( $\mathrm{T}=24{ }^{\circ} \mathrm{C}$ and $\mathrm{pH}=8.1$ ) and the expected ocean warming and acidification $\left(\mathrm{T}=28{ }^{\circ} \mathrm{C}\right.$ and $\left.\mathrm{pH}=7.6\right)$, as well as proper $\mathrm{PhE}$ concentration ( $\left.0.8 \mathrm{ng} . \mathrm{I}^{-1}\right)$ during 28 days. In all exposures, higher PhE contents were observed under hypercapnia and warming condition in the digestive gland and gills, followed by the mantle and muscle. Generally, the results visibly reveal that longer exposure period led to promote $\mathrm{PhE}$ bioaccumulation in all tissues under ocean warming and acidification environment which was timedependent pattern of PhE accumulation in P.radiata. Present-day PhE environmental concentrations, which combined with ocean warming and acidification, may lead to rigorous interruption of physiological functions can be extra threatened the ecological fitness of pearl oysters.

\section{Introduction}

The notable rise of the anthropogenic effects on the earth such as continuous population growth, extreme use of natural resources, and excessive production of pollutants, remarkably since the mid-20th century, has led to climate change (Maulvault et al. 2018). Since industrial revolution era, relevant atmospheric carbon dioxide concentrations have been increasing ( $\simeq 400 \mathrm{CO} 2 \mu$ atm in our time), and are predicted that by the year 2100, it will be reached nearly 1000 CO2 $\mu$ atm (IPCC 2014; Nardi et al. 2018a). Increased anthropogenic $\mathrm{COQ}$, accompanied by other gases, brings about a constant increase in global mean ocean temperatures because of greenhouse effect, and estimates indicate a worldwide temperature rise between $0.3^{\circ} \mathrm{C}$ to $4.8^{\circ} \mathrm{C}$ near the end of 21 st century (IPCC 2014). Concurrently, global mean ocean pH will be decreased approximately 0.13 to 0.42 units by the year 2100 , caused by dissolving atmospheric $\mathrm{CO} \otimes$ in the ocean, leading to increase hydrogen ion $(\mathrm{H}+)$ accessibility and to change seawater carbonate chemistry i.e. ocean acidification (IPCC 2014). Ocean acidification and global warming are taken into consideration main menaces to marine biodiversity (Byrne and Przeslawski 2013; Kroeker et al. 2013; Nardi et al. 2017; Sampaio et al. 2017). Antagonistic biological effects have been extensively recognized in numerous species with regard to altered physiological stress responses (such as Benedetti et al. 2016; Rosa et al. 2016; Nardi et al. 2018b; Sampaio et al. 2018), weakened energy metabolism (Ivanina et al. 2013; Rodolfo-Metalpa et al. 2014), changed immune response (Bibby et al. 2008; Hernroth et al. 2011; Nardi et al. 2017). Simultaneously dealing with global warming and acidification, marine organisms are also exposed to another main stressor: contamination. Polycyclic Aromatic hydrocarbons (PAHs) are one of the most concerning chemicals in the marine environment. PAHs are toxic, bioactive and carcinogenic, mutagenic and ubiquitous environmental compounds composed of 2-7 fused aromatic rings derived 
from pyrogenic, petrogenic and biogenic sources(Ke et al. 2017; Wang et al. 2018; Akhbarizadeh et al. 2019). These large group are different in degrees of resistance to degradation and persistence, tending to be accumulated in marine biota because of their high hydrophobic and lipophilic properties ( Leitão et al. 2017; Sarkar et al., 2017; Lima et al., 2018; Akhbarizadeh et al., 2019) due to their toxicity and prevalent environmental existence and readily cumulating by biota (Neff and Anderson 1981), 16 PAHs have seen on the US EPA priority pollutant list (US EPA 2009). Phenanthrene (PHE), an important 3-ring component of crude oil and a representative from the US-EPA priority pollutant list, as a consequence of anthropological activities (US EPA, 2009), is one of the most abundant aquatic PAH. since It is lipophilic and has a low molecular weight, it easily is absorbed by marine biota (Oliveira et al. 2007; Pan et al. 2006; Hannam et al. 2010; Lüchmann et al. 2014, 2015).

Contaminant effects and its uptake are hypothetically altered via reduced $\mathrm{pH}$ or raised temperature and contrariwise (Noyes et al. 2009; Sampaio et al. 2018). As for the bioaccumulation PAHs, which was also affected by temperature levels (Muijs and Jonker 2009; Lima et al. 2018), studies involving pH are markedly rare and, apparently, the present report is the first to discover the influence of $\mathrm{pH}$ accompanied by temperature on the bioaccumulation of PAHs compounds. Nevertheless, antagonistic and synergistic effects of increased temperature coupled with decreased $\mathrm{pH}$ on bioaccumulation of some heavy metals such as cadmium and mercury have been determined in aquatic organisms ( Pimentel et al. 2015; Benedetti et al. 2016; Rosa et al. 2016; Nardi et al. 2017, 2018a, 2018b; Sampaio et al. 2016, 2017a, 2018). To provide new perceptions on interactive effects between low $\mathrm{pH}$ and high temperature, and organic contaminants, this study investigated whether differential combinations of $\mathrm{pH}$ and temperature may influence on PAHs accumulation in the pearl oyster Pinctada radiata. This species, extensively spread all over Persian Gulf, has been taken into account as commercial species.

Bivalve mollusks have typically been chosen as the most appropriate organisms for pollution monitoring programs. Due to their inactive habits, filter-feeding behaviors, low metabolism in contrast to vertebrates and for their ability to accumulate pollutants (Pempkowiak et al. 2006). Bivalve species like clams, oysters and mussels bioaccumulate PAHs more than other marine biota(Al-Hashem, 2017). Due to its widely distribution, pearl oyster (Pinctada radiata) is particularly good biomonitors and susceptible to PAHs accumulation. They mirror PAH exposure because of being sessile and having low ability to metabolize and remove this compounds (Al-Hashem 2017). To understand how the pearl oysters will cope with PAH and the anticipated climate change conditions may afford precious documents on future stock population situation. From this perspective, we carried out a 28-day experiment under future ocean conditions to examine how interacting stressors moderate PAHs bioaccumulation in the oyster. To present an extensive interpretation of organic contaminant accumulation, we evaluated how organdependent PAHs bioaccumulation (digestive gland, gills, muscle and mantle) was moderated by decreasing $\mathrm{pH}\left(\Delta \mathrm{pH}=0.5\right.$ unit) and increasing temperature $\left(\Delta \mathrm{T}=4^{\circ} \mathrm{C}\right)$, and evaluated the direct effects of combined and isolated climate stressor exposure on the organism.

\section{Method And Material}




\section{Animal collection and experimental setup}

Adult pearl oyster, Pinctada radiate, (mean \pm SD, $4.8 \pm 0.6 \mathrm{~cm}$ shell length) were acquired in November 2018 from Hendorabi Island of Persian Gulf, Iran. They were transferred to the Shrimp Research Institute established in Busher province via land for $12 \mathrm{~h}$, in a container containing oxygen-saturated air and seawater. Upon arrival, samples were categorized and acclimatized in several 300 I tanks for two weeks with aerated filtered seawater at following local environmental conditions: salinity (35 PSU), temperature $\left(24^{\circ} \mathrm{C}\right), \mathrm{pH}(8.1), \mathrm{O}_{2}$ concentration $\left(4.5 \pm 2.1 \mathrm{mg} . \mathrm{I}^{-1}\right)$, total alkalinity $\left(2521.34 \pm 1.52 \mu \mathrm{mol} . \mathrm{kg}^{-1}\right)$ and natural photoperiod.

Following 14 days of laboratory acclimation, Oysters were exposed during 28 days to four crossed treatment combinations of two $\mathrm{pH}$ levels ( 7.6 and $8.1, \Delta \mathrm{pH}=0.5$ units), two temperature levels ( 24 and $28^{\circ} \mathrm{C}, \Delta \mathrm{T}=4^{\circ} \mathrm{C}$ ) and PHE pollutant. Experimental setup was categorized in four exposure treatments with triplicate aquaria per treatment and each aquaria containing 15 animals in $20 \mathrm{~L}$, as follow: 1) contaminant condition (PhE) $24^{\circ} \mathrm{C}$ and normocapnia with $\mathrm{pH} 8.1$ unit, $24^{\circ} \mathrm{C}$ and $0.8 \mathrm{ng} / \mathrm{L}$ phenanthrene; 2) hypercapnia condition and $\mathrm{PhE}(\mathrm{A}-\mathrm{PhE}), 24^{\circ} \mathrm{C}, \mathrm{pH} 7.6$ and $0.8 \mathrm{ng} / \mathrm{L}$ phenanthrene ; 3 ) warming condition and $\mathrm{PhE}$ (W-PhE), $28^{\circ} \mathrm{C}, \mathrm{pH} 8.1$ and $0.8 \mathrm{ng} / \mathrm{L}$ phenanthrene; 4) hypercapnia and warming conditions and $\mathrm{PhE}(\mathrm{A}-\mathrm{W}-\mathrm{PhE}), 28^{\circ} \mathrm{C}, \mathrm{pH} 7.6$ and $0.8 \mathrm{ng} / \mathrm{L}$ phenanthrene. Phenanthrene concentration was selected as representative of a contaminated but realistic environmental situation in Persian Gulf waters (Aagh et al., 2016), whereas temperature levels and pH in control condition are typically experienced by oysters during the Persian Gulf autumn season. Chosen proposal $\mathrm{pH}$ and temperature were based on climate change scenario (IPCC 2014; Wong et al. 2014) where a mean pH decreasing value of 0.5 unit and a mean temperature increasing level of $4^{\circ} \mathrm{C}$ is predicted for Open Ocean.

The hypercapnic condition was regulated by blending seawater (SW) with $\mathrm{pH} 8.1$ with small amounts of CO2-saturated seawater, attained through bubbling pure $\mathrm{CO} 2$ into the filtered seawater for at least $24 \mathrm{~h}$, to reach the desired pH (7.6) (Liu et al. 2012; Schulz et al. 2013; Nardi et al. 2017) To ensure steadiness for the duration of the experiment, the $\mathrm{pH}$ of each level in the experimental aquaria was measured three times daily before and after water exchange using a pH meter ( $\mathrm{HQ} 40 \mathrm{~d}$, Hach) calibrated with standard buffers. Before adding into the aquaria, seawater was reached to targeted temperature and seawater temperatures in raised up temperature was kept by aquarium heather in each experimental aquaria. Phenanthrene (PhE) (98\% purity, Sigma-Aldrich) was dissolved in acetone and then added to each experimental exposure aquaria (PhE, A-PhE, W-PhE, A-W-PhE), to reach a final nominal the PhE concentration of $0.8 \mathrm{ng} . \mathrm{L}^{-1}$ and final acetone concentration was lower than $0.01 \%$ of the aquaria volume. Temperatures were measured three times daily with a mercury thermometer. Water was exchanged every day, and oysters were fed $12 \mathrm{~h}$ before renewing the water with a commercial algae concentration of cheatocerous. No mortalities were observed in any of the control and treated groups after 28 days.

\section{Phenanthrene Analysis In Seawater And Oysters}


After $24 \mathrm{~h}, 48 \mathrm{~h}$ and 28 days of exposure to increased temperature, decreased $\mathrm{pH}$ and $\mathrm{PHE}$, five animals from each experimental tank were randomly selected for PhE measurement in chosen soft tissues of the animals. Five oysters from each treatment aquarium were sacrified and gills, digestive gland (D.g), mantle and adductor muscle were instantly frozen in liquid nitrogen and then individually kept at $-80^{\circ} \mathrm{C}$ for phenanthrene content.

In order to validate the phenanthrene concentration variations in the exposure aquaria during the experiment, $1 \mathrm{~L}$ of seawater was collected from each treatment immediately after adding the initial phenanthrene and before exchanging the seawater. One liter seawater sample was taken in separotory funnel and extracted by typical liquid-liquid extraction with dichloromethane at volumes of 50,30 , and $20 \mathrm{ml}$. The extract was condensed to nearly $5 \mathrm{~mL}$ by a rotary evaporator. Under mild flow of purified nitrogen gas, the condensed extract volume was compressed and then, the extract was redisssolved into $1 \mathrm{ml}$ of acetonitrile.

Phenanthrene extraction from tissue oyster samples were carried out using ultrasonication procedure described by according to Kumar et al. (2014) Barhoumi et al. (2016) and Akhbarizadeh et al. (2019) with some modifications. Briefly, Approximately $2 \mathrm{~g}$ of the oyster tissue was freeze-dried and homogenized. Then, each prepared sample was powdered and extracted by ultrasonic bath using $50 \mathrm{ml}$ mixture hexaneacetone $(1: 1 \mathrm{v} / \mathrm{v})$. To eliminate sulfuric compounds in the sample, approximately $5 \mathrm{~g}$ activated Cu powder was put into the extract and left for 24h. After that, the extracts were let to sediment and solvent layer was filtered via a Whatman 41 filter paper containing anhydrous sodium sulphate. Rotary evaporator was employed for condensing the solvent extract to get approximately $2 \mathrm{~mL}$. Subsequently, the analyte was concentrated to $0.5 \mathrm{ml}$ under gentle $\mathrm{N} 2$ flow and then, it was dissolved in $1 \mathrm{~mL}$ acetonitrile. To measure the analyte of interest, the extract was injected into HPLC with fluorescence detector (Hodgeson et al. 1990). PhE was identified via the retention time comparison with standard solution and analytical procedures were examined processing bland and reference samples (Mussel Tissue Standard Reference Material GBW0871, EERC-CAS).

\section{Statistical Analyses}

For the PhE concentrations, Shapiro-Wilks test was carried out for Normality and homogeneity of variances assumptions were checked by Bartlett's test. When necessary, data were normalized using the logarithmic transformation. Generalized linear models (GLM) analysis was conducted to determine significant differences between group treatments. Levene's and Shapiro- Wilk tests were performed to verify homogeneity of variance and residuals normality respectively. investigative variables or factors were generally used including Temperature $(\mathrm{T})$ in 2 levels: $24^{\circ} \mathrm{C}, 28^{\circ} \mathrm{C}, \mathrm{pH}(\mathrm{pH})$ in 2 levels: 8.1 unit, 7.5 unit, time sampling (time) in 3 levels: $24 \mathrm{~h}, 48 \mathrm{~h}$ and 28 days and organ tissue sampled (Tissue) in 4 levels: Gills, Digestive gland, Muscle and Mantle, according to phenanthrene bioaccumulation as a dependent variable. The Akaike Information Criterion (AIC), a prevalent indicator, was performed to obtain best model selection proper for our data that equilibrates model complication with model quality of 
fitness (Quinn and Keough 2002). Parameters that did not affect data difference were eliminated and thus, models were simplified. Gaussian family was used to fit the data. To confirm final models, model residuals were controlled for homogeneity of variances, independence and leverage. Finally, to provide $F$ and $p$ values for factors with more than two levels, ANOVA test was performed. All statistical analyses were carried out for a significance level of 0.05 , on $R$ studio software (version 1.3.1093). To visualize the differences among various treatments and tissues, GraphPad Prism software (version 8.0.1) was applied.

\section{Results}

After 28 days of experimental exposure, no mortality was recorded in any exposure aquarium. The $\mathrm{PhE}$ concentration at different treatments were calculated in water of each aquaria. The concentrations of $\mathrm{PhE}$ in water retained at contaminant condition (PhE), hypercapnia condition and $\mathrm{PhE}$, warming condition and $\mathrm{PhE}+$ hypercapnia + warming conditions were, respectively, $60.1,61.34,50.16$ and $45.54 \%$ of the initial nominal concentration in the tanks, after 28 days of experiment.

Total phenanthrene concentrations in whole body displayed significant differences between various treatment exposures (GLM, $t=11.24, p<0.001$, ANOVA $F$ test, $F=126.4, p<0.001)$. The lowest and highest concentrations were measured in contaminant condition (Contaminant \&Hypercapnia $p<0.01$ / Contaminant \& Warming $p<0.001$ / Contaminant \& Hypercapnia + Warming 0.001, GLM analysis in table 1) and hypercapnia with warming scenario (Contaminant\& Hypercapnia + Warming $p<0.001 /$ Hypercapnia\& Hypercapnia + Warming $p<0.001 /$ warming\& Hypercapnia + Warming $p<0.01$, GLM analysis in table 1, Fig. 1.A) respectively.

Table 1 GLM analysis of Pradiata Phenanthrene bioaccumulation in whole body in different treatment exposure. Model formula on top, family and respective model AIC in the bottom. Est-Estimates; Std ErrorStandard Error.

\begin{tabular}{|lcccc|}
\hline & EST & Std Error & T value & p \\
\hline GLM: PhE in function of treatment exposure & & & \\
\hline Intercept & 13.21 & 0.26 & 51.33 & $<0.001$ \\
\hline Contaminant\&Hypercapnia & 1.41 & 0.36 & 3.87 & $<0.01$ \\
\hline Contaminant \& Warming & 2.34 & 0.36 & 6.430 & $<0.001$ \\
\hline Contaminant \& Hypercapnia + Warming & 3.69 & 0.36 & 10.15 & $<0.001$ \\
\hline Hypercapnia\& Warming & 0.93 & 0.39 & 56.8 & $<0.05$ \\
\hline Hypercapnia \& Hypercapnia + Warming & 2.28 & 0.36 & 6.28 & $<0.001$ \\
\hline Warming\& Hypercapnia + Warming & 1.35 & 0.36 & 3.72 & $<0.01$ \\
\hline Family = Gaussian & & & AlC $=19.796$ \\
\hline
\end{tabular}


Bioaccumulation of PhE showed significant differences between different tissues (GLM, $t=-9.311, p<$ 0.001 ) which revealed tissue-specific trend (ANOVA $F$ test, $F=37.54, p<0.001$ ). PhE concentration was higher in the digestive gland (D.g\& Mantle/ D.g \& Muscle $p<0.001$ GLM analysis Table 2) and muscle tissue showed lower PhE concentration (D.g \& Muscle/ Gill\& mantle $p<0.001$ GLM analysis Table 2, Fig. 1.B).

Table 2

GLM analysis of Pradiata Phenanthrene bioaccumulation in different tissues. Model formula on top, family and respective model AIC in the bottom. Est-Estimates; Std Error-Standard Error.

\begin{tabular}{|c|c|c|c|c|}
\hline & EST & Std Error & T value & $\mathbf{p}$ \\
\hline \multicolumn{5}{|c|}{ GLM: PhE in function of tissue } \\
\hline Intercept & 3.47 & 0.15 & 22.95 & $<0.001$ \\
\hline Gill\& D.g & -0.06 & 0.21 & -0.28 & 0.781 \\
\hline Gill\& Mantle & -1.55 & 0.21 & -7.25 & $<0.001$ \\
\hline Gill\& Muscle & -1.7 & 0.21 & -7.99 & $<0.001$ \\
\hline D.g\& Mantle & -1.5 & 0.21 & -6.97 & $<0.001$ \\
\hline D.g \& Muscle & -1.65 & 0.21 & -7.7 & $<0.001$ \\
\hline Mantle\& Muscle & -0.16 & 0.21 & -0.73 & 0.464 \\
\hline \multicolumn{3}{|l|}{ Family = Gaussian } & \multicolumn{2}{|c|}{$\mathrm{AIC}=389.7$} \\
\hline
\end{tabular}

Phenanthrene concentrations in gill tissue revealed significant differences between $\mathrm{pH}$ levels $(\mathrm{t}=-3.5, \mathrm{p}<$ 0.01 GLM analysis in Table 3, ANOVA $F$ test, $F=12.22, p<0.01)$ and temperature levels $(t=11.52, p<$ 0.001, GLM analysis in Table 3, ANOVA F test, $F=132.72, p<0.001$ ).

PhE accumulation increased in oysters gill in the time of exposure for $24,48 \mathrm{~h}$ and 28 days to $0.8 \mathrm{ng} . \mathrm{L}^{-1}$ of phenanthrene (Time1\&Time2/Time1\&Time3/Time2\&Time3, GLM analysis, Table 3). As seen in Table 3 , significant additive effect on phenanthrene bioaccumulation between increasing temperature and decreasing $\mathrm{pH}$ interaction was not detected. Regarding the results, there was no significant interactive effect on bioaccumulation when both stressors and the time of exposure combined. In other words, isolated stressors caused to increase and affect PhE concentrations in gill tissue. 
Table 3

GLM analysis of Pradiata Phenanthrene bioaccumulation in Gill tissue. Model formula on top, family and respective model AIC in the bottom. Est-Estimates; Std Error-Standard Error.

\begin{tabular}{|c|c|c|c|c|}
\hline & EST & Std Error & t value & $\mathbf{p}$ \\
\hline \multicolumn{5}{|c|}{ GLM: Gill PHE in function of $\mathrm{pH}^{\star} \mathrm{Temp}^{\star}$ time } \\
\hline Intercept & 2.68 & 0.055 & 52.65 & $<0.001$ \\
\hline $\mathrm{pH}$ & -0.16 & 0.04 & -3.5 & $<0.01$ \\
\hline Temp & 0.52 & 0.04 & 11.52 & $<0.001$ \\
\hline Time1\&time2 & 0.42 & 0.055 & 7.73 & $<0.001$ \\
\hline Time1\&time3 & 1.48417 & 0.05 & 26.9 & $<0.001$ \\
\hline Time2\&Time3 & 1.05 & 0.05 & 19.114 & $<0.001$ \\
\hline
\end{tabular}

Under experimental condition, phenanthrene concentration in digestive gland significantly increased in elevated $\mathrm{CO} 2$ and temperature as a single stressor $(\mathrm{t}=-2.92, \mathrm{p}<0.01$ for $\mathrm{pH}, \mathrm{t}=4.33, \mathrm{p}<0.001$ for temperature, GLM analysis in Table 4, ANOVA F test, $F=8.56, p<0.01$, for $p H, F=106.3, p<0.001$ for temperature). It follows from our results (Table 4) that the phenanthrene bioaccumulation in $P$. radiata digestive gland considerably increased over the exposure time (Table 4). At the end of the experiment, the bioaccumulated PhE was higher by 2-fold than at the first of the experiment. A significant extra effect between rising temperature and the exposure time was observed, leading to higher PhE accumulation in the tissue $\left(T e m p 28^{\circ} \mathrm{C} \&\right.$ time2, $t=3.14, p<0.01$, GLM analysis in Table 4, ANOVA F test, $F=6.006, p<$ $0.01)$. 
Table 4

GLM analysis of Pradiata Phenanthrene bioaccumulation in

Digestive gland tissue. Model formula on top, family and

respective model AIC in the bottom. Est-Estimates; Std Error-

Standard Error.

\begin{tabular}{|c|c|c|c|c|}
\hline & EST & Std Error & t value & $\mathbf{p}$ \\
\hline \multicolumn{5}{|c|}{ GLM: Digestive gland PHE in function of $\mathrm{pH}^{\star}$ Temp*time } \\
\hline Intercept & 2.33 & 0.085 & 27.38 & $<0.001$ \\
\hline $\mathrm{pH}$ & -0.19 & 0.06 & -2.92 & $<0.01$ \\
\hline Temp & 0.48 & 0.11 & 4.33 & $<0.001$ \\
\hline Time1\&time2 & 0.21 & 0.11 & 1.88 & 0.0697 \\
\hline Time1\&time3 & 2.31 & 0.11 & 20.75 & $<0.001$ \\
\hline Time2\&time3 & 2.1 & 0.11 & 18.87 & $<0.001$ \\
\hline Temp24C\&time1 & 0.5 & 0.15 & 3.139 & $<0.01$ \\
\hline Temp24C\&time2 & -0.49 & 0.16 & -3.13 & $<0.01$ \\
\hline Temp24C\&time3 & -0.047 & 0.15 & -0.3 & 0.77 \\
\hline Temp $28^{\circ} \mathrm{C} \&$ time2 & 0.49 & 0.16 & 3.14 & $<0.01$ \\
\hline Temp $28^{\circ} \mathrm{C} \&$ time3 & 0.047 & 0.15 & 0.29 & 0.77 \\
\hline \multicolumn{5}{|c|}{ Family = Gaussian AIC= -8.0051} \\
\hline
\end{tabular}

The impact of elevated $\mathrm{CO} 2$, warming and the exposure of time on phenanthrene accumulation in the oyster mantle is shown in Table 5 . PhE concentrations were differently affected by various stressors in the tissue (GLM analysis in Table 5). The contaminant reported higher levels in the exposure time 3 (28 days, $t=22.32, p<0.001$ and $t=28, p<0.001$, GLM analysis in Table 5, ANOVA $F$ test, $F=135, p<0.001$ ) and lower in the interaction of pH 8.1 time $1(24 \mathrm{~h}$, positively) and pH 8.1 time2 ( $48 \mathrm{~h}$, negatively) $(\mathrm{t}=0.13$ $p<0.001, t=-0.13 p<0.001$ respectively. GLM analysis in Table 5), but these were not significant. Looking at Table 5, PhE concentration was positively affected by $\mathrm{pH} 7.6$ with the exposure time $3(28$ days) and temperature $28^{\circ} \mathrm{C}$ with the exposure time $3(28$ days $)(t=3.76, t=4.22 \mathrm{p}<0.001 \mathrm{GLM}$ analysis in Table 5). Nevertheless, $\mathrm{pH} 8.1$ and the exposure time 3 (28 days) interactively was negatively affected showing an antagonistic relation within the mantle $(t=-3.76, p<0.01$, GLM analysis in Table 5). 
Table 5

GLM analysis of Pradiata Phenanthrene bioaccumulation in Mantle tissue. Model formula on top, family and respective model AIC in the bottom. Est-Estimates; Std Error-Standard Error.

\begin{tabular}{|c|c|c|c|c|}
\hline & EST & Std Error & t value & p \\
\hline \multicolumn{5}{|c|}{ GLM: Mantle PHE in function of $\mathrm{pH}^{\star}$ Temp*time } \\
\hline Intercept & 1.04 & 0.04 & 22.04 & 0.001 \\
\hline $\mathrm{pH}$ & -0.12 & 0.05 & -2.36 & 0.05 \\
\hline Temp & 0.41 & 0.05 & 7.7 & 0.001 \\
\hline time1\&time2 & 0.38 & 0.066 & 5.7 & 0.001 \\
\hline Time1\&time3 & 1.86 & 0.07 & 28 & 0.001 \\
\hline Time2\&time3 & 1.48 & 0.06 & 22.32 & 0.001 \\
\hline pH8.1\&time1 & 0.01 & 0.07 & 0.13 & 0.9 \\
\hline pH8.1\&time2 & -0.01 & 0.08 & -0.13 & 0.9 \\
\hline pH8.1\&time3 & -0.29 & 0.08 & -3.76 & 0.01 \\
\hline pH7.6\&time1 & -0.01 & 0.07 & -0.13 & 0.897 \\
\hline pH7.6\&time2 & 0.01 & 0.07 & 0.16 & 0.89 \\
\hline pH7.6\&time3 & 0.29 & 0.076 & 3.76 & $<0.001$ \\
\hline Temp28c\&time1 & 0.06 & 0.08 & 0.781 & 0.44 \\
\hline Temp28c\&time2 & -0.06 & 0.076 & -0.781 & 0.44 \\
\hline Temp28c\&time3 & 0.32 & 0.077 & 4.22 & 0.001 \\
\hline
\end{tabular}

The phenanthrene concentrations in muscle tissue were also significantly affected by temperature, $\mathrm{pH}$ and the exposure time between treatment exposures (Table 6). According the findings, Pradiata muscle analysis revealed higher effect on PhE concentration in the exposure time 3 (28days, GLM analysis in Table 3) in comparison to other times and stressors in all treatments. Lower effect on PhE concentration was seen in normal condition $(\mathrm{pH}=8.1$, temp $=24 \mathrm{C})$ in time $2(48 \mathrm{~h})$ but it was not significant (ANOVA F test, $F=0.039, p=0.84, t=-0.11, p=0.9$, GLM analysis in Table 6). 
Table 6

GLM analysis of Pradiata Phenanthrene bioaccumulation in Muscle tissue. Model formula on top, family and respective model AIC in the bottom. Est-Estimates; Std Error-Standard Error.

\begin{tabular}{|c|c|c|c|c|}
\hline & EST & Std Error & t value & p \\
\hline \multicolumn{5}{|c|}{ GLM: Muscle PHE in function of $\mathrm{pH}^{\star}$ Temp*time } \\
\hline Intercept & 0.9 & 0.06 & 14.63 & $<0.001$ \\
\hline $\mathrm{pH}$ & -0.17 & 0.07 & -2.47 & $<0.05$ \\
\hline Temp & 0.34 & 0.07 & 4.8 & $<0.01$ \\
\hline time1\&time2 & 0.35 & 0.08 & 4.01 & $<0.001$ \\
\hline Time1\&time3 & 1.9 & 0.09 & 21.87 & $<0.001$ \\
\hline Time2\&time3 & 1.56 & 0.08 & 17.86 & $<0.001$ \\
\hline pH8.1\& Temp24 & -0.02 & 0.15 & -0.13 & -0.9 \\
\hline pH8.1\&time1 & -0.04 & 0.1 & -0.38 & 0.7 \\
\hline pH8.1*time2 & 0.03 & 0.1 & 0.38 & 0.7 \\
\hline pH8.1*time3 & -0.29 & 0.1 & -2.87 & $<0.01$ \\
\hline pH7.6\&time1 & 0.04 & 0.1 & 0.38 & 0.7 \\
\hline pH7.6\&time2 & -0.038 & 0.1 & -0.38 & 0.7 \\
\hline pH7.6\&time3 & 0.32 & 0.1 & 3.25 & $<0.01$ \\
\hline Temp24C\&time1 & 0.055 & 0.1 & 0.54 & 0.59 \\
\hline Temp24C\&time2 & -0.05 & 0.1 & -0.54 & 0.59 \\
\hline Temp24C\&time3 & -0.26 & 0.1 & -2.56 & $<0.05$ \\
\hline Temp28C\&time1 & 0.05 & 0.1 & -0.54 & 0.6 \\
\hline Temp28C*time2 & -0.05 & 0.1 & 0.54 & 0.6 \\
\hline Temp28C*time3 & 0.31 & 0.1 & 3.1 & 0.01 \\
\hline Temp24C\&time2 & -0.04 & 0.15 & -0.29 & 0.77 \\
\hline Temp24C\&time3 & -0.26 & 0.14 & -1.75 & 0.09 \\
\hline pH8.1\&Temp24C\&time2 & -0.23 & 0.21 & -0.11 & 0.9 \\
\hline pH8.1\&Temp24C\&time3 & -0.1 & 0.21 & -0.5 & 0.62 \\
\hline
\end{tabular}




\section{Discussion}

As for the effects of ocean warming and acidification on pollutant bioaccumulation, the contemporary shortage of experimental investigations focusing on the PAHs bioaccumulation, prevents acceptable comparisons of the results gained in the present study with previous studies. Thus, the present research presented new evidence that future predictions of elevated $\mathrm{pCO} 2$ and increased temperature in Persian Gulf waters can modify pollutant accumulation of phenanthrene in the pearl oyster Pradiata.

Our findings revealed that the $P$. radiata were able to concentrate low molecular weight PhE from seawater. The reduction in phenanthrene concentrations in water after $24 \mathrm{~h}$ is probable to display the bioavailability and uptake of the contaminant(Skadsheim et al. 2009; Hannam et al. 2010; Lüchmann et al. 2014). Neff and Anderson (1981) reported that phenanthrene is readily and rapidly taken up by organisms. To retain phenanthrene exposure level and water quality, despite the large uptake of this PAH by $P$. radiata, it was necessary to exchange the water and add proper $\mathrm{PhE}$ concentration in regularity (every $24 \mathrm{~h}$ ). Some PHE is lost because of adsorption onto the surface of the both the oyster shells and experiment tank walls ( Hannam et al. 2010; Xie et al. 2017; Lima et al. 2018), degradation, volatilization or other unknown mechanism during the exposure time ( Hannam et al. 2010; Lima et al. 2018).

Though elevated temperature and decreased $\mathrm{pH}$ have been proposed to affect on bioaccumulation of trace metals (Benedetti et al. 2016; Nardi et al. 2017, 2018a,b; Sampaio et al. 2016, 2018), our study is one of the first to present findings about the effect of ocean climate changes on phenanthrene (as a PAHs model) bioaccumulation in a marine organism. Regarding the increased temperature and decreased $\mathrm{pH}$, the same patterns observed when both stressors acted in combination and isolation (after 28 days of exposure, PhE concentration in whole body of oyster: $A+W$ significantly higher than $W$ and $A$; $W$ significantly higher than $A$ and contaminant condition; and contaminant condition significantly lower than A), highlighted the significance and urgent of considering the interactions between various abiotic stressors in studies focused on contaminants' exposure specifically in the circumstance of climate change.

Relevant to the acidification effect, as detected in PhE bioaccumulation due to metabolic changes under hypercapnia condition, the accumulation of pollutant could be increased. It has also been documented in some investigations (e.g. Benedetti et al. 2016; Rosa et al. 2016; Sampaio et al. 2016, 2017; Nardi et al. $2017,2018 a, b)$.

Some authors state that damages in apical epithelial membrane simplify chemical diffusion into cells (Freitas et al. 2016; Shi et al. 2016; Velez et al. 2016; Sampaio et al. 2016, 2017a; Maulvault et al. 2018). Due to bivalves have a valve closing strategy of protection when exposed to environmental stressors, minor pollutant elimination in hypercapnia condition (increased $\mathrm{PCO}_{2}$ ) have been previously reported thus, preventing the excretion of compounds and their metabolites into the environment (Freitas et al. 2016; Velez et al. 2016; Maulvault et al. 2018). Such dispute may explain the lower elimination of phenanthrene and its metabolites under increased $\mathrm{PCO}_{2}$. Because of current lack knowledge about PAHs 
bioaccumulation under hypercapnia condition, it is not possible to compare the present data with previous studies on bivalves PAHs accumulation under climate change conditions however, some authors state that lower $\mathrm{pH}$ facilitate the uptake of molecular forms of pollutants ( e.g Higgins and Luthy 2005; Wang et al. 2012; Maulvault et al. 2018).

By increasing animals' metabolism, consequently, enhancing oyster ventilation and feeding rates in response to higher metabolic demands (Dijkstra et al. 2013), raised seawater temperature could probable lead to higher contaminant bioaccumulation in biota (Shen et al. 2010; Sampaio et al. 2016; Maulvault et al. 2017, 2018; Nardi et al. 2018a). Hence, phenanthrene can accumulate in soft tissue due to its lipophilic behavior (Speciale et al. 2018) and low elimination rate under warming seawater condition. Due to increasing filtration rate under high temperature and the low ability of bivalves in PAHs compounds elimination and metabolism capacity, phenanthrene was bioaccmulated in the oyster soft tissues (Bougrier et al. 1995; Haure et al. 1998; Xiao et al. 2014; Hannam et al. 2010; Piazza et al. 2016; Lima et al. 2018; Livingstone 1998; Snyder 2000). Previous studies have been found the bioaccumulation of this compound in some bivalves such as Crassostrea brasiliana (Lima et al. 2018), Chlamys islandica (Hannam et al. 2009), Pecten maximus (Hannam et al. 2010), Mytilus edulis (Law et al. 1999; Moore et al. 2007), Mytilus galloprovincialis (Valavanidis et al. 2008) and Crassostrea virginica (Elder and Dresler 1988). Although Lima et al. (2018) stated that PhE half-life in water was lower in high temperature, the higher concentration $\mathrm{PhE}$ in whole soft tissue at $\mathrm{W}$ and $\mathrm{A}-\mathrm{W}$ treatments can be related to renew the contaminant every $24 \mathrm{~h}$. Both stressors in combination, enhanced temperature and $\mathrm{PCO} 2$, had synergetic spontaneity effect on PhE accumulation in oyster soft tissues. Previous studies on the effect of climate changes on metallic contaminant bioaccumulation revealed no synergic effects of both stressors(Benedetti et al. 2016; Nardi et al. 2018a, b; Sampaio et al. 2017, 2018). Nevertheless, additional investigations, especially focused on effects of the future scenario on PAHs bioaccumulation, need to be carried out to give more information about the synergistic or additive effects of these stressors.

While ocean acidification and warming seawater temperature have been indicated to impact on bioconcentration of trace metals (Baines et al. 2005; Mubiana and Blust 2007; Lacoue-Labarthe et al. 2011, 2009; Götze et al. 2014; Nardi et al. 2018a, 2017; Sampaio et al., 2017, 2018), it has not been documented the effects of this scenario on PAHs bioaccumulation. In the present study, the consequences of experiments revealed higher significant concentration of phenanthrene in the gills digestive gland of $p$. radiata exposed to this contaminant than mantle and muscle. Our findings showed no difference of phenanthrene uptake in between digestive gland and gills of oysters exposed to the chemical at lower $\mathrm{pH}$ and/or higher temperature, as well as between mantle and muscle. These findings revealed that the impact of enhancing temperature and $\mathrm{pCO} 2$ on phenanthrene bioconcentration cannot be popularized, depending on biota and the PAHs compounds, hence it is difficult to forecast only from the chemical model.

Our best AIC model indicated that contaminant bioaccumulation influenced by ocean warming and acidification which is coincident with previous studies (Benedetti et al. 2016; Nardi et al. 2017, 2018a, b, Sampaio et al. 2017, 2018). Similarity for phenanthrene bioaccumulation differed amongst oyster tissues 
with enhancing PhE concentration as follows: digestive gland $>$ gills $>$ mantle $>$ muscle. The findings are supported by previous study carried out by Shahbazi et al. (2010) on PAHs tissue preferential bioaccumulation. The digestive gland is an organ commonly considered for its fundamental role in contaminate accumulation, detoxification and transformation and being responsible for recirculation of contaminants to other tissues, where the contaminant accumulate at higher concentration, compared to mantle and muscle tissues mostly characterized for low contaminant affinity (Yamashita et al. 2005; Jezierska and Witeska 2006; Wang et al. 2012; Sampaio et al. 2017; Maulvault et al. 2017, 2018). Furthermore, because of its high lipophilic property, PAHs concentrates specially in lipid-rich organs, like digestive gland (Guzzi and La Porta. 2008; Maulvault et al. 2016, 2017; Sampaio et al. 2018). Moreover, Being responsible for osmoregulation, acid base balance, nitrogenous waste excretion and respiration, as multifunctional organs, gills are sensitive organs to extensive various chemicals in water (Osman et al. 2017). Besides, due to increased blood supply, gill organs similarly recognized to have higher contaminate affinity in comparison to other organs ( Jezierska and Witeska 2006; Vergilio et al. 2012; Sampaio et al. 2017) such as mantle and muscle organs. Consequently, chronic exposure of oysters to contaminants in their surrounding water and sediments may eventually damage their respiratory ability.

In present study, PhE concentration in all of oyster organs increased during the exposure time. Liu et al. (2014) Liu et al. (2014) reported B[a]P concentration in gill and digestive gland of clam Ruditapes philippinarum increased during the exposure experiment. Other authors also stated that other bivalves exposing $\mathrm{B}[\mathrm{a}] \mathrm{P}$ revealed increasing in contaminant bioaccumulation in their gill and digestive gland tissues. There was no significant differences between two organs (Pan et al. 2008; Wang et al. 2011). Our results are coincident with the former, though the accumulation of $\mathrm{PhE}$ in gills and digestive glands were higher than two other tissues (mantle, muscle) during the exposure time; there was no statistically significant differences between digestive gland and gills with mantle and muscle. Bioaccumulation of organic pollutants in aquatic organisms is a balance between principally passive processes of uptake and depuration and elimination of contaminants through biotransformation pathways ( Livingstone 1991). Nonetheless, PAHs metabolism are significantly less than uptake rates in mollusks, resulting in strong bioaccumulation (Livingstone 1998; Liu et al. 2014).

Since oysters are filter-feeder and sessile creatures frequently exposed to PAH compounds in their habitat (Lima et al. 2018), revealing low ability to metabolize and eliminate these compounds (Siebert et al. 2017; Lima et al. 2018), PhE bioaccumulation in oyster different tissues is anticipated. When oysters were exposed under acidic condition, statistically significant increase of phenanthrene uptake was found during the experiment time in each tissue. The effect of reduced $\mathrm{pH}$ on PAHs uptake may not be influenced by the chemical compounds, but slightly reveal physiological effects of increasing PCO2 on an organism, which cannot be popularized, depending on PAHs, tissue, exposure time and species-specific individuals (Benedetti et al. 2016; Nardi et al. 2017, 2018b). The impact of enhancing temperature on increased PhE bioaccumulation was observed in all tissues, suggesting a whole organism physiological response, and tissue-specific variations. Increasing PhE concentration in different organs may be due to arrangement prioritization of $\mathrm{CO} 2$-excretory physiological processes under hypercapnia condition during exposure time (Perry et al. 1988; Sampaio et al. 2016, 2017). Therefore, taking into consideration that 
presence of both warming temperature and decreasing $\mathrm{pH}$ stressors cause to reduce physiological and subsequently metabolic thresholds (Harvey et al. 2013; Rosa et al. 2013; Sampaio et al. 2016, 2017). It may play a key role to arrest the contaminant in these organs because of decreasing the metabolic processes. Following the depression of total metabolism in the organism, the PhE metabolism and elimination, and excretion will be also reduced, thus it leads to accumulate the contaminant in these organs. In general, these consequences verify the limited effect of ocean acidification in comparison to temperature on the bioaccumulation of phenanthrene, despite the fact that there are statistically significant differences between the two stressors. Storage lipids, lipid composition and membrane phospholipids are the main partitioning places for the contaminant and to preserve ideal membrane functioning and availability to the energy pool, the lipid phases are retained fluid over an extensive temperature range. Fluctuation of temperature leads to change in lipid composition especially partition behavior of PAHs (Hazel 1995; Holmstrup et al. 2007; Muijs and Jonker 2009). Partitioning to these fluid lipids is enthalpy-driven (Wezel and Opperhuizen 1995; Muijs and Jonker 2009), which subsequently should terminate in positive temperature effect. Additionally, tri- and tetra aromatic compounds are generally accumulated at larger concentrations in bivalves or other marine creatures than the weightier aromatic compounds. Some previous studies revealed such composition pattern in bivalves ( Porte and Albaigés 1994; Baumard et al. 1999; Hong et al. 2016; Ma et al. 2017). PAHs accumulation can be accomplished directly by taking in of low molecular weight PAH compounds via their branches (gills) and indirectly through digestion of fine grain size fraction of sediment and suspended particles, after that, absorption of higher molecular weight PAHs by the gastrointestinal tract and then distribute in other orangs (Oros and Ross. 2005; Ma et al., 2017). Possessing high lipophilic property and being the smallest $\mathrm{PAH}$, as one of global persistent organic pollutants, $\mathrm{PhE}$ be capable of simply penetrating biological membranes and contributes to bioaccumulate readily and rapid in different tissues (Zhang et al. 2014; Jin et al. 2015; Noh et al. 2015; Xiu et al. 2015; Piazza et al. 2016; Speciale et al. 2018) with noticeable tendency for bioaccumulation in digestive gland (Osman et al. 2017).

In the present study, GLM analysis in different organs revealed the time- dependent pattern of PhE uptake. time-dependent pattern of B[a]P uptake was confirmed in scallop's ovary (Tian et al. 2014). It is plausible to assume that this pattern could be proceeded to saturate the organs completely during the experiment or feasibly the PhE levels were saturated in all tissues of P.radiata before the exposure time has been finished. Similar saturation patterns were also found for other marine biota exposed to various contaminants and temperatures. Oyster Crassostrea brasiliana exposed to phenanthrene at 18, 24 and $32^{\circ} \mathrm{C}$ (Lima et al. 2018), mussels M. galloprovincialis exposed to cadmium at 20 and $25^{\circ} \mathrm{C}$ (Nardi et al. 2017), and fish $P$. flavescens exposed to $\mathrm{Ni}$ at three temperature levels of 9,20 and $28^{\circ} \mathrm{C}$ (Grasset et al. 2016) presented similar elevated levels of contaminants in high temperatures during the time of experiments.

\section{Conclusion}

In present study, chronic exposure of pearl oysters to conditions mimicking the climate changes which may occur in 50-100 years later and accomplished by phenanthrene as a contaminant model, is able to 
affect the bioaccumulation levels of $\mathrm{PhE}$ in oyster soft tissues confirming pollutant accumulation would be influenced by increasing temperature and PCO2. In our experimental conditions oyster tissues showed significant PhE accumulation, partially at least, influenced by the increased and modulated metabolic activity under elevated seawater temperature and PCO2 in isolation and combination in the marine organism. In particular, bioaccumulation changes appeared to be dependent on duration of exposure to $\mathrm{PhE}$ and the condition of the experiments. Thus, uptake of components such as $\mathrm{PhE}$ can be different in a species and tissue-specific aspect, emphasizing the need of further investigation to explain the effect of several stressors, principally in species with high commercial or ecological importance.

\section{Declarations}

Acknowledgments: the authors acknowledge ENG Hossein Rameshi for providing pearl oyster for the trail and Shrimp Research Institute in Busher province, Iran for providing the place for conducting the experiment.

Ethics approval and consent to participate: All applicable international, national, and/or institutional guidelines for the care and use of animals were followed.

Consent to Participate: not applicable

Consent for publication: not applicable

Availability of data and material: Raw data were obtained by authors derived data supporting the finding of this study is available from the corresponding author on request.

Competing interest: We (all authors) declare that we have no significant competing financial, professional, or personal interest that might have influenced the performance of the work described in this manuscript.

Funding: No funding

Authors' contributions: Fatemeh Jafari: Design of the experiment, carried out the experiment, analysis of the raw data, writing of the first draft. Akram Sadat Naeemi: Design of the experiment, reviewing and editing of the manuscript. Mohsen Noorinezhad: carried out the experiment, analysis of the raw data. Mohammad Mahdi Sohani: carried out the experiment, analysis of the raw data. All authors discussed the results and contributed to the final manuscript.

\section{References}

1. Aagh H, Rahmanpour S, Abedi E, Arebi I, Mahdinia A (2016) Contamination of polycyclic aromatic hydrocarbons in seawater and sediments of West-Northern coasts of the Persian Gulf. Indian J Mar Sci 45(12):1688-1695. 
2. Akhbarizadeh, R., Moore, F. and Keshavarzi, B. (2019) Polycyclic aromatic hydrocarbons and potentially toxic elements in seafood from the Persian Gulf: presence, trophic transfer , and chronic intake risk assessment. Environ Geochem Health. https://doi.org/10.1007/s10653-019-00343-1.

3. Al-Hashem MA (2017) Gill Histopathological Effects of PAHs on Adult Pearl Oyster, Pinctada radiata at Al-Khiran Coast in Kuwait. J Environ Prot 8(2):109-119. https://doi.org/10.4236/jep.2017.82009.

4. Baines SB, Fisher N S, Kinney E L (2005) Influence of temperature on dietary metal uptake in Arctic and temperate mussels. Mar Ecol Prog Ser 289:201-213.

5. Barhoumi B, El Megdiche Y, Clérandeau C, Ameur WB, Mekni S, Bouabdallah S, Derouiche A, Touil S, Cachot J, Driss M R (2016) Occurrence of polycyclic aromatic hydrocarbons (PAHs) in mussel (Mytilus galloprovincialis) and eel (Anguilla anguilla) from Bizerte lagoon, Tunisia, and associated human health risk assessment. Cont Shelf Res 124:104-116. https:// doi.org/10.1016/j.csr.2016.05.012.

6. Baumard P, Budzinski H, Garrigues P, Dizer H, Hansen PD (1999) Polycyclic aromatic hydrocarbons in recent sediments and mussels (Mytilus edulis) from the Western Baltic Sea: Occurrence, bioavailability and seasonal variations. Mar Environ Res 47(1):17-47. https:// doi.org/10.1016/S0141-1136(98)00105-6.

7. Baussant T, Bechmann RK, Taban IC, Larsen BK, Tandberg AH, Bjørnstad A, Torgrimsen S, Nævdal A, Øysæd KB, Jonsson G, et al. (2009) Enzymatic and cellular responses in relation to body burden of PAHs in bivalve molluscs: A case study with chronic levels of North Sea and Barents Sea dispersed oil. Mar Pollut Bull 58(12):1796-1807. https:// doi.org/10.1016/j.marpolbul.2009.08.007.

8. Benedetti M, Lanzoni I, Nardi A, d'Errico G, Di Carlo M, Fattorini D, Nigro M, Regoli F (2016) Oxidative responsiveness to multiple stressors in the key Antarctic species, Adamussium colbecki: Interactions between temperature, acidification and cadmium exposure. Mar Environ Res 121:20-30. https://doi.org/10.1016/j.marenvres.2016.03.011.

9. Bibby R, Widdicombe S, Parry H, Spicer J, Pipe R (2008) Effects of ocean acidification on the immune response of the blue mussel Mytilus edulis. Aquat Biol 2 (1):67-74. htttps:// doi.org/10.3354/ab00037.

10. Bougrier S, Geairon P, Deslous-Paoli JM, Bacher C, Jonquières G (1995) Allometric relationships and effects of temperature on clearance and oxygen consumption rates of Crassostrea gigas (Thunberg). Aquaculture, 134:143-154. https:// doi.org/10.1016/0044-8486(95)00036-2.

11. Byrne M, Przeslawski R (2013) Multistressor impacts of warming and acidification of the ocean on marine invertebrates' life histories. Integr Comp Biol 53(4):582-596. https:// doi.org/10.1093/icb/ict049.

12. Devier MH, Augagneur S, Budzinski H, Le Menach K, Mora P, Narbonne JF, Garrigues P (2005) Oneyear monitoring survey of organic compounds (PAHs, PCBs, TBT), heavy metals and biomarkers in blue mussels from the Arcachon Bay, France. J Environ Monit 7 (3):224-240. https:// doi.org/10.1039/b409577d. 
13. Dijkstra JA, Buckman KL, Ward D, Evans DW, Dionne M, Chen CY (2013) Experimental and Natural Warming Elevates Mercury Concentrations in Estuarine Fish. PLoS ONE, 8(3):1-9. https://doi.org/10.1371/journal.pone.0058401.

14. Elder JF, Dresler PV (1988) Accumulation and bioconcentration of polycyclic aromatic hydrocarbons in a nearshore estuarine environment near a Pensacola (Florida) creosote contamination site. Environ Pollut 49(2):17-132. https://doi.org/10.1016/0269-7491(88)90244-8.

15. Freitas R, Pires A, Velez C, Almeida Â, Moreira A, Wrona FJ, Soares AMVM, Figueira E (2016) Effects of seawater acidification on Diopatra neapolitana (Polychaete, Onuphidae): Biochemical and regenerative capacity responses. Ecol Indic 60:152-161. https://doi.org/10.1016/j.ecolind.2015.06.032.

16. Götze S, Matoo OB, Beniash E, Saborowski R, Sokolova IM (2014) Interactive effects of CO2 and trace metals on the proteasome activity and cellular stress response of marine bivalves Crassostrea virginica and Mercenaria mercenaria. Aquat Toxicol 149:65-82. https:// doi.org/10.1016/j.aquatox.2014.01.027.

17. Grasset J, Ollivier É, Bougas B, Yannic G, Campbell PGC, Bernatchez L, Couture P (2016) Combined effects of temperature changes and metal contamination at different levels of biological organization in yellow perch. Aquat Toxicol 177:324-332. https:// doi.org/10.1016/j.aquatox.2016.06.008.

18. Guzzi GP, La Porta CAM (2008) Molecular mechanisms triggered by mercury. Toxicology, 244 (1):112. https://doi.org/10.1016/j.tox.2007.11.002.

19. Hannam ML, Bamber SD, Galloway TS, John Moody A, Jones MB (2010) Effects of the model PAH phenanthrene on immune function and oxidative stress in the haemolymph of the temperate scallop Pecten maximus. Chemosphere 78 (7):779-784.

https://doi.org/10.1016/j.chemosphere.2009.12.049.

20. Hannam ML, Bamber SD, Moody JA, Galloway TS, Jones MB (2009) Immune function in the Arctic Scallop, Chlamys islandica, following dispersed oil exposure. Aquat Toxicol 92(3):187-194. https://doi.org/10.1016/j.aquatox.2009.01.010.

21. Harvey BP, Gwynn-Jones D, Moore PJ (2013) Meta-analysis reveals complex marine biological responses to the interactive effects of ocean acidification and warming. Ecol Evol 3(4):1016-1030. https:// doi.org/10.1002/ece3.516.

22. Haure J, Penisson C, Bougrier S, Baud JP (1998) Influence of temperature on clearance and oxygen consumption rates of the flat oyster Ostrea edulis: Determination of allometric coefficients. Aquaculture, 169 (3-4):211-224. https:// doi.org/10.1016/S0044-8486(98)00383-4.

23. Hazel JR (1995) Thermal adaptation in biological membranes: Is homeoviscous adaptation the explanation? Annu Rev Physiol 57(94):19-42. https:// doi.org/10.1146/annurev.ph.57.030195.000315.

24. Hernroth B, Baden S, Thorndyke M, Dupont S (2011) Immune suppression of the echinoderm Asterias rubens (L.) following long-term ocean acidification. Aqua Toxicol 103(3-4):222-224. 
https://doi:10.1016/j.aquatox.2011.03.001.

25. Higgins CP, Luthy RG (2005) Supporting Information Sorption of Perfluorinated Surfactants on Sediments. Anal Chem 2: 1-11.

26. Hodgeson JW, Bashe WJ, Baker TV (1990) US EPA METHOD 550.1. Determination of Polycyclic Aromatic Hydrocarbons in Drinking Water By Liquid-Solid Extraction and Hplc With Coupled ultraviolet and fluorescence detection. Envirometnal Protection Agency, Washington, D.C.,July 1990. http://w.ultrasci.com/docs/analyticalmethod/method_550_1.pdf.

27. Holmstrup M, Sørensen LI, Bindesbøl AM, Hedlund K (2007) Cold acclimation and lipid composition in the earthworm Dendrobaena octaedra. Comp Biochem Physiol Part A Mol Integr Physiol, 147(4):911-919. https://doi.org/10.1016/j.cbpa.2007.02.019.

28. Hong WJ, Jia H, Li YF, Sun Y, Liu X, Wang L (2016) Polycyclic aromatic hydrocarbons (PAHs) and alkylated PAHs in the coastal seawater, surface sediment and oyster from Dalian, Northeast China. Ecotox Environ Safe 128:11-20. https:// doi.org/10.1016/j.ecoenv.2016.02.003.

29. IPCC (2014) Climate change 2014:impacts,adaptation,and vulnerablity.In: Contribution of Working Group II to the Fifth Assessment Report of the Intergovermental Panel on Climate Change. Cambridge University Press, Cambridge,United Kingdom and New York, NY, USA. pp. 1820.

30. Ivanina AV, Dickinson GH, Matoo OB, Bagwe R, Dickinson A, Beniash E, Sokolova IM (2013) Interactive effects of elevated temperature and CO2levels on energy metabolism and biomineralization of marine bivalves Crassostrea virginica and Mercenaria mercenaria. Comp Biochem Physiol Part A Mol Integr Physiol 166 (1): 101-111. https:// doi.org/10.1016/j.cbpa.2013.05.016.

31. Jin Q, Pan L, Liu T, Hu F (2015) RNA-seq based on transcriptome reveals differ genetic expressing in Chlamys farreri exposed to carcinogen PAHs. Environ Toxicol Phar 39(1):313-320. https://doi.org/10.1016/j.etap.2014.11.019.

32. Ke CL, Gu YG, Liu Q, Li LD, Huang HH, Cai N, Sun ZW (2017) Polycyclic aromatic hydrocarbons (PAHs) in wild marine organisms from South China Sea: Occurrence, sources, and human health implications. Mar Pollut Bull 117(1-2):507-511.https:// doi.org/10.1016/j.marpolbul.2017.02.018.

33. Kroeker KJ, Kordas RL, Crim R, Hendriks IE, Ramajo L, Singh GS, Duarte CM, Gattuso JP (2013) Impacts of ocean acidification on marine organisms: Quantifying sensitivities and interaction with warming. Glob Change Biol 19 (6):1884-1896. https:// doi.org/10.1111/gcb.12179.

34. Kumar B, Verma VK, Gaur R, Kumar S, Sharma CS, Akolkar AB (2014) Validation of HPLC method for determination of priority polycyclic aromatic hydrocarbons (PAHS) in waste water and sediments. Adv Appl Sci Res 5(1):201-209.

35. Lacoue-Labarthe T, Martin S, Oberhänsli F, Teyssié JL, Markich S, Ross J, Bustamante P (2009) Effects of increased pCO2 and temperature on trace element (Ag, $\mathrm{Cd}$ and $\mathrm{Zn}$ ) bioaccumulation in the eggs of the common cuttlefish, Sepia officinalis. Biogeosciences 6(11):2561-2573. https:// doi.org/10.5194/bg-6-2561-2009. 
36. Lacoue-Labarthe T, Réveillac E, Oberhänsli F, Teyssié JL, Jeffree R, Gattuso JP (2011) Effects of ocean acidification on trace element accumulation in the early-life stages of squid Loligo vulgaris. Aquat Toxicol 105(1-2):166-176. https:// doi.org/10.1016/j.aquatox.2011.05.021.

37. Law RJ, Kelly CA, Nicholson MD (1999) Polycyclic aromatic hydrocarbons (PAH) in shellfish affected by the Sea Empress oil spill in Wales in 1996. Polycycl Aromat Comp 17(1-4):229-239. https://doi.org/10.1080/10406639908020618.

38. Leitão A, Al-Shaikh I, Hassan H, Ben Hamadou R, Bach S (2017) First genotoxicity assessment of marine environment in Qatar using the local Pearl oyster Pinctada radiata. Reg Stud Mar Sci 11:2331. htpps

://doi.org/10.1016/j.rsma.2017.02.001.

39. León VM, Moreno-gonzález R, González E, Martínez F, García V, Campillo JA (2013) Science of the Total Environment Interspeci fi c comparison of polycyclic aromatic hydrocarbons and persistent organochlorines bioaccumulation in bivalves from a Mediterranean coastal lagoon. Sci Total Environ 463-464:975-987. https://doi.org/10.1016/j.scitotenv.2013.06.075.

40. Lima D, Zacchi FL, Mattos JJ, Flores-Nunes F, Gomes CHA de M, de Mello ÁCP, Siebert MN, Piazza CE, Taniguchi S, Sasaki ST, et al. (2018) Molecular and cellular effects of temperature in oysters Crassostrea brasiliana exposed to phenanthrene. Chemosphere 209:307-318. https://doi.org/10.1016/j.chemosphere.2018.06.094.

41. Liu D, Pan L, Li Z, Cai Y, Miao J (2014) Metabolites analysis, metabolic enzyme activities and bioaccumulation in the clam Ruditapes philippinarum exposed to benzo[a]pyrene. Ecotoxicol Environ Saf 107:251-259. https://doi.org/10.1016/j.ecoenv.2014.06.024.

42. Liu W, Huang X, Lin J, He M (2012) Seawater acidification and elevated temperature affect gene expression patterns of the pearl oyster Pinctada fucata. PLoS ONE 7(3):e33679. https://doi.org/10.1371/journal.pone.0033679.

43. Livingstone DR (1991) Organic Xenobiotic Metabolism in Marine Invertebrates. In: Gilles R (ed) Advances in Comparative and Enviromental Physiology. Speringer, Berlin, pp 45-185. https://doi.org/10.1007/978-3-642-75897-3_2.

44. Livingstone DR (1998) The fate of organic xenobiotics in aquatic ecosystems: Quantitative and qualitative differences in biotransformation by invertebrates and fish. Comp Biochem Physiol part A Mol Integr Physiol 120(1):43-49. https://doi.org/10.1016/S1095-6433(98)10008-9.

45. Lüchmann KH, Clark MS, Bainy ACD, Gilbert JA, Craft JA, Chipman JK, Thorne MAS, Mattos JJ, Siebert MN, Schroeder DC (2015) Key metabolic pathways involved in xenobiotic biotransformation and stress responses revealed by transcriptomics of the mangrove oyster Crassostrea brasiliana. Aquat Toxicol 166:10-20. https://doi.org/10.1016/j.aquatox.2015.06.012.

46. Lüchmann KH, Dafre AL, Trevisan R, Craft JA, Meng X, Mattos JJ, Zacchi FL, Dorrington TS, Schroeder DC, Bainy ACD (2014) A light in the darkness: New biotransformation genes, antioxidant parameters and tissue-specific responses in oysters exposed to phenanthrene. Aquat Toxicol 152:324-334. https://doi.org/10.1016/j.aquatox.2014.04.021. 
47. Ma L, Lu ZQ, Zhang YB, Zhao X, Yang SY (2017) Distribution and sources apportionment of polycyclic aromatic hydrocarbons in the edible bivalves and sipunculida from coastal areas of Beibu Gulf, China. Appl Ecol Environ Res 15(3):1211-1225. https://doi.org/10.15666/aeer/1503_12111225.

48. Maulvault AL, Barbosa V, Alves R, Custódio A, Anacleto P, Repolho T, Pousão Ferreira P, Rosa R, Marques A, Diniz M (2017) Ecophysiological responses of juvenile seabass (Dicentrarchus labrax) exposed to increased temperature and dietary methylmercury. Sci Total Environ 586:551-558. hppts:// doi.org/10.1016/j.scitotenv.2017.02.016.

49. Maulvault AL, Camacho C, Barbosa V, Alves R, Anacleto P, Fogaça F, Kwadijk C, Kotterman M, Cunha SC, Fernandes JO, et al. (2018) Assessing the effects of seawater temperature and $\mathrm{pH}$ on the bioaccumulation of emerging chemical contaminants in marine bivalves. Environ Res 161:236-247. https://doi.org/10.1016/j.envres.2017.11.017.

50. Maulvault AL, Custódio A, Anacleto P, Repolho T, Pousão P, Nunes M L, Diniz M, Rosa R, Marques A (2016) Bioaccumulation and elimination of mercury in juvenile seabass (Dicentrarchus labrax) in a warmer environment. Environ Res 149:77-85. https://doi.org/10.1016/j.envres.2016.04.035.

51. Moore MN, Viarengo A, Donkin P, Hawkins AJS (2007) Autophagic and lysosomal reactions to stress in the hepatopancreas of blue mussels. Aquat Toxicol 84(1):80-91. https://doi.org/10.1016/j.aquatox.2007.06.007.

52. Mubiana VK, Blust R (2007) Effects of temperature on scope for growth and accumulation of Cd, Co, $\mathrm{Cu}$ and $\mathrm{Pb}$ by the marine bivalve Mytilus edulis. Mar Environ Res 63(3):219-235. https://doi.org/10.1016/j.marenvres.2006.08.005.

53. Muijs B, Jonker MTO (2009) Temperature-Dependent Bioaccumulation of Polycyclic Aromatic Hydrocarbons. Environ Sci Technol 43(12):4517-4523.

54. Nardi A, Benedetti M, d'Errico G, Fattorini D, Regoli F (2018a) Effects of ocean warming and acidification on accumulation and cellular responsiveness to cadmium in mussels Mytilus galloprovincialis. Importance of the seasonal status. Aquat Toxicol 204:171-179. https://doi.org/10.1016/j.aquatox.2018.09.009.

55. Nardi A, Benedetti M, Fattorini D, Regoli F (2018b) Oxidative and interactive challenge of cadmium and ocean acidification on the smooth scallop Flexopecten glaber. Aquat Toxicol 196:53-60. https:// doi.org/10.1016/j.aquatox.2018.01.008.

56. Nardi A, Mincarelli LF, Benedetti M, Fattorini D, d'Errico G, Regoli F (2017) Indirect effects of climate changes on cadmium bioavailability and biological effects in the Mediterranean mussel Mytilus galloprovincialis. Chemosphere 169:493-502. https://doi.org/10.1016/j.chemosphere.2016.11.093.

57. Neff JM, Anderson JW (1981) Response of marine animals to petroleum and specific petroleum hydrocarbons. Applied Science Publishers Ltd, London.

58. Noh SR, Cheong HK, Ha M, Eom SY, Kim H, Choi YH, Paek D (2015) Oxidative stress biomarkers in long-term participants in clean-up work after the Hebei Spirit oil spill. Sci Total Environ 515516:207-214. https://doi.org/10.1016/j.scitotenv.2015.02.039. 
59. Noyes PD, McElwee MK, Miller HD, Clark BW, Van Tiem LA, Walcott KC, Erwin KN, Lenin ED (2009) The toxicology of climate change: environmental contaminant in warming world. Environ Int 35(6):971-986.

60. Oliveira M, Pacheco M, Santos MA (2007) Cytochrome P4501A, genotoxic and stress responses in golden grey mullet (Liza aurata) following short-term exposure to phenanthrene. Chemosphere 66(7):1284-1291. https://doi.org/10.1016/j.chemosphere.2006.07.024.

61. Oros DR, Ross JRM (2005) Polycyclic aromatic hydrocarbons in bivalves from the San Francisco estuary: Spatial distributions, temporal trends, and sources (1993-2001). Mar Environ Res 60(4):466-488. https://doi.org/10.1016/j.marenvres.2005.02.001.

62. Osman G, Galal M, Abul-Ezz A, Ahmad M, Abul-Ela M, Hegazy AM (2017) Polycyclic aromatic hydrocarbons (PAHS) accumulation and histopathological biomarkers in gills and mantle of Lanistes carinatus (Molluscs, Ampullariidae) to assess crude oil toxicity. Punjab Univ J zool 32(1):39-50.

63. Pan L, Miao J, Wang J, Liu J (2008) AHH activity , tissue dose and DNA damage in different tissues of the scallop Chlamys farreri exposed to benzo [ a ] pyrene. Eviron Pollut 153:192-198. https://doi.org10.1016/j.envpol.2007.07.022.

64. Pan LQ, Ren J, Liu J (2006) Responses of antioxidant systems and LPO level to benzo(a)pyrene and benzo(k)fluoranthene in the haemolymph of the scallop Chlamys ferrari. Environ Pollut 141(3):443451. https://doi.org/10.1016/j.envpol.2005.08.069.

65. Pempkowiak J, Pazdro K, Kopecka J, Perez E, Sole M (2006) Toxicants accumulation rates and effects in Mytilus trossulus and Nereis diversicolor exposed separately or together to cadmium and PAHs. J Environ Sci Health A 41(11):2571-2586. https://doi.org/10.1080/10934520600927963.

66. Perry SF, Walsh PJ, Mommsen TP, Moon TW (1988) Metabolic consequences of hypercapnia in the rainbow trout, Salmo gairdneri: $\beta$-Adrenergic effects. Gen Comp Endocrinol 69(3):439-447. https://doi.org/10.1016/0016-6480(88)90036-6.

67. Piazza RS, Trevisan R, Flores-Nunes F, Toledo-Silva G, Wendt N, Mattos JJ, Lima D, Taniguchi S, Sasaki ST, Mello ÁCP, et al. (2016) Exposure to phenanthrene and depuration: Changes on gene transcription, enzymatic activity and lipid peroxidation in gill of scallops Nodipecten nodosus. Aquat Toxicol 177:146-155. https://doi.org/10.1016/j.aquatox.2016.05.025.

68. Pimentel MS, Faleiro F, Diniz M, Machado J, Pousão-Ferreira P, Peck MA, Pörtner HO, Rosa R (2015) Oxidative stress and digestive enzyme activity of flatfish larvae in a changing ocean. PLoS ONE 10(7):1-18. https://doi.org/10.1371/journal.pone.0134082.

69. Porte C, Albaigés J (1994) Bioaccumulation patterns of hydrocarbons and polychlorinated biphenyls in bivalves, crustaceans, and fishes. Arch Environ Contam Toxicol 26(3):273-281. https://doi.org/10.1007/BF00203552.

70. Quinn GP, Keough MJ (2002) Exprimental design and data analysis for biologists. Cambridge University Press, London. 
71. Rodolfo-Metalpa R, Hoogenboom MO, Rottier C, Ramos-Esplá A, Baker AC, Fine M, Ferrier-Pagès $C$ (2014) Thermally tolerant corals have limited capacity to acclimatize to future warming. Glob Change Biol 20(10): 3036-3049. https://doi.org/10.1111/gcb.12571.

72. Rosa R, Ricardo Paula J, Sampaio E, Pimentel M, Lopes AR, Baptista M, Guerreiro M, Santos C, Campos D, Almeida-Val VMF, et al. (2016) Neuro-oxidativ:e damage and aerobic potential loss of sharks under elevated CO2and warming. Mar Biol 163(5)119-129. https://doi.org/10.1007/s00227016-2898-7.

73. Rosa R, Tru K, Repolho T, Pimentel M, Faleiro F, Boavida-portugal J, Baptista M, Leal MC, Calado R, Lopes VM, et al. (2013). Lower hypoxia thresholds of cuttlefish early life stages living in a warm acidified ocean. Proc R Soc B 280:1-7. http://dx.doi.org/10.1098/rspb.2013.1695.

74. Sampaio E, Lopes AR, Francisco S, Paula JR, Pimentel M, Ana L (2017a) Ocean acidification dampens warming and contamination effects on the physiological stress response of a commercially important fish. Biogeosciences ??:1-27. https:://doi.org/10.5194/bg-2017-147.

75. Sampaio E, Lopes AR, Francisco S, Paula JR, Pimentel M, Maulvault AL, Repolho T, Grilo TF, PousãoFerreira P, Marques A, et al. (2018) Ocean acidification dampens physiological stress response to warming and contamination in a commercially-important fish (Argyrosomus regius). Sci Total Environ 618:388-398. https://doi.org/10.1016/j.scitotenv.2017.11.059.

76. Sampaio E, Maulvault AL, Lopes VM, Paula JR, Barbosa V, Alves R, Pousao-Ferreira P, Repolho T, Marques A, Rosa R (2016) Habitat selection disruption and lateralization impairment of cryptic flatfish in a warm, acid, and contaminated ocean. Mar Biol 163(10):1-10. https://doi.org/10.1007/s00227-016-2994-8.

77. Sampaio E, Rodil IF, Vaz-Pinto F, Fernández A, Arenas F (2017b) Interaction strength between different grazers and macroalgae mediated by ocean acidification over warming gradients. Mar Environ Res 125:25-33. https://doi.org/10.1016/j.marenvres.2017.01.001.

78. Sarkar A, Bhagat J, Saha Sarker M, Gaitonde DCS, Sarker S (2017) Evaluation of the impact of bioaccumulation of PAH from the marine environment on DNA integrity and oxidative stress in marine rock oyster (Saccostrea cucullata) along the Arabian sea coast. Ecotoxicology, 26(8):11051116. https://doi.org/10.1007/s10646-017-1837-9.

79. Schulz KG, Bellerby RGJ, Brussaard CPD, Büdenbender J, Czerny J, Engel A, Fischer M, Koch-Klavsen S, Krug SA, Lischka S, et al. (2013) Temporal biomass dynamics of an Arctic plankton bloom in response to increasing levels of atmospheric carbon dioxide. Biogeosciences 10(1):161-180. https://doi.org/10.5194/bg-10-161-2013.

80. Shahbazi A, Zakaria MP, Yap CK, Tan SG, Surif S, Mohamed CAR, Sakari M, Bakhtiari AR, Bahry PS, Chandru K, et al. (2010) Use of Different Tissues of Perna Viridis as Biomonitors of Polycyclic Aromatic Hydrocarbons (PAHs) in the Coastal Waters of Peninsular Malaysia. Environ Forensics 11(3):248-263. https://doi.org/10.1080/15275920903558513.

81. Shen L, Reiner EJ, Macpherson KA, Kolic TM, Sverko E, Helm PA, Bhavsar SP, Brindle ID, Marvin CH (2010) Identification and screening analysis of halogenated norbornene flame retardants in the 
Laurentian Great Lakes: Dechloranes 602, 603, and 604. Environ Sci Technol 44(2):760-766. https://doi.org/10.1021/es902482b.

82. Shi W, Zhao X, Han Y, Che Z, Chai X, Liu G (2016) Ocean acidification increases cadmium accumulation in marine bivalves: A potential threat to seafood safety. Sci Rep 6:1-8. https:// doi.org/10.1038/srep20197.

83. Siebert MN, Mattos JJ, Piazza CE, de Lima D, Gomes CHAM, de Melo CMR, Bainy ACD (2017) Characterization of ethoxyresorufin 0-deethylase activity (EROD) in oyster Crassostrea brasiliana. Comp Biochem Physiol B Biochem Mol Biol 203:115-121. https://doi.org/10.1016/j.cbpb.2016.10.002.

84. Skadsheim A, Sanni S, Pinturier L, Moltu UE, Buffagni M, Bracco L (2009) Assessing and monitoring local and long-range-transported hydrocarbons as potential stressors to fish stocks. Deep-Sea Res Part II: Top Stud Oceanogr 56 (21-22):2037-2043. https://doi.org/10.1016/j.dsr2.2008.11.014.

85. Snyder MJ (2000) Cytochrome P450 enzymes in aquatic invertebrates: Recent advances and future directions. Aquat Toxicol 48(4):529-547. https://doi.org/10.1016/S0166-445X(00)00085-0.

86. Speciale A, Zena R, Calabrò C, Bertuccio C, Aragona M, Saija A, Trombetta D, Cimino F, Lo Cascio P (2018) Experimental exposure of blue mussels (Mytilus galloprovincialis) to high levels of benzo[a]pyrene and possible implications for human health. Ecotoxicol Environ Saf 150:96-103. https://doi.org/10.1016/j.ecoenv.2017.12.038.

87. Tian S, Pan L, Zhang H (2014) Identification of a CYP3A-like gene and CYPs mRNA expression modulation following exposure to benzo[a]pyrene in the bivalve mollusk Chlamys farreri. Mar Environ Res 94:7-15. https://doi.org/10.1016/j.marenvres.2013.11.001.

88. Turja R, Soirinsuo A, Budzinski H, Devier MH, Lehtonen KK (2013) Biomarker responses and accumulation of hazardous substances in mussels (Mytilus trossulus) transplanted along a pollution gradient close to an oil terminal in the Gulf of Finland (Baltic Sea). Comp Biochem Physiol C Toxicol Pharmacol 157(1):80-92. https://doi.org/10.1016/j.cbpc.2012.09.006.

89. US EPA (2009) United States Enviromental Protection Agency Priority Pollutants Website, http://www.epa.gov/waterscience/methods/pollutants.html.

90. Valavanidis A, Vlachogianni T, Triantafillaki S, Dassenakis M, Androutsos F, Scoullos M (2008) Polycyclic aromatic hydrocarbons in surface seawater and in indigenous mussels (Mytilus galloprovincialis) from coastal areas of the Saronikos Gulf (Greece). Estuar Coast Shelf Sci 79(4):733-739. https://doi.org/10.1016/j.ecss.2008.06.018.

91. Velez C, Figueira E, Soares AMVM, Freitas R (2016) Combined effects of seawater acidification and salinity changes in Ruditapes philippinarum. Aquat Toxicol 176:141-150. https://doi.org/10.1016/j.aquatox.2016.04.016.

92. Vergilio CS, Carvalho CEV, Melo EJT (2012) Accumulation and Histopathological Effects of Mercury Chloride after Acute Exposure in Tropical Fish Gymnotus carapo. J Chem Health Risks 2(4):1-8.

93. Wang F, Liu C, Shih K (2012) Adsorption behavior of perfluorooctanesulfonate (PFOS) and perfluorooctanoate (PFOA) on boehmite. Chemosphere 89(8):1009-1014. 
https://doi.org/10.1016/j.chemosphere.2012.06.071.

94. Wang H, Li Y, Xia X, Xiong X (2018) Relationship between metabolic enzyme activities and bioaccumulation kinetics of PAHs in zebrafish (Danio rerio). J Environ Sci (China) 65:43-52. https://doi.org/10.1016/j.jes.2017.03.037.

95. Wang L, Pan L, Liu N, Liu D, Xu C, Miao J (2011) Biomarkers and bioaccumulation of clam Ruditapes philippinarum in response to combined cadmium and benzo[a]pyrene exposure. Food Chem Toxicol 49(12):3407-3417. https://doi.org/10.1016/j.fct.2011.06.015.

96. Wezel AP, Opperhuizen A (1995) Thermodynamics of partitioning of a series of chlorobenzenes to fish storage lipids, in comparison to partitioning to phospholipids. Chemosphere, 31(7):3605-3615. https://doi.org/10.1016/0045-6535(95)00209-Q.

97. Xiao BC, Li EC, Du ZY, Jiang RL, Chen LQ, Yu N (2014) Effects of temperature and salinity on metabolic rate of the Asiatic clam Corbicula fluminea (Müller, 1774). SpringerPlus 3(1):1-9. https://doi.org/10.1186/2193-1801-3-455.

98. Xie J, Zhao C, Han Q, Zhou H, Li Q, Diao X (2017) Effects of pyrene exposure on immune response and oxidative stress in the pearl oyster, Pinctada martensii. Fish Shellfish Immunol 63:237-244. https://doi.org/10.1016/j.fsi.2017.02.032.

99. Xiu M, Pan L, Jin Q (2014) Bioaccumulation and oxidative damage in juvenile scallop Chlamys farreri exposed to benzo[a]pyrene, benzo[b]fluoranthene and chrysene. Ecotoxicol Environ Saf 107:103-110. https:// doi.org/10.1016/j.ecoenv.2014.05.016.

100. Xiu M, Pan L, Jin Q, Miao J (2015) Gender differences in detoxification metabolism of polycyclic aromatic hydrocarbon (chrysene) in scallop Chlamys farreri during the reproduction period. Comp Biochem Physiol C Toxicol Pharmacol 170:50-59. https:// doi.org/10.1016/j.cbpc.2015.02.003.

101. Yamashita N, Kannan K, Taniyasu S, Horii Y, Petrick G, Gamo T (2005) A global survey of perfluorinated acids in oceans. Mar Pollut Bull 51 (8-12):658-668.

https://doi.org/10.1016/j.marpolbul.2005.04.026.

102. Zhang H, Pan L, Tao Y (2014) Toxicity assessment of environmental pollutant phenanthrene in clam Venerupis philippinarum using oxidative stress biomarkers. Environ Toxicol Pharmacol 37(2):697704. https://doi.org/10.1016/j.etap.2014.01.018.

\section{Figures}



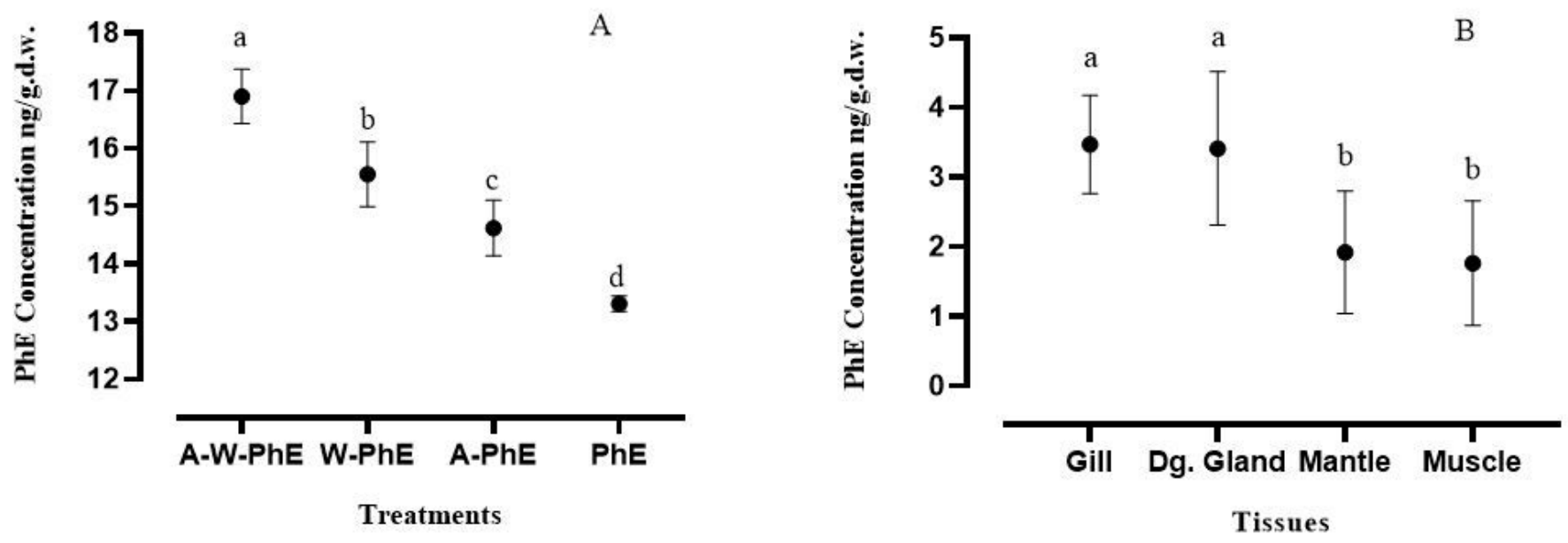

Figure 1

A. Phenanthrene concentration in whole body of P.radiata in different treatments. B. Phenanthrene concentration in different tissues of P.radiata. 